The Journal of Public Space

ISSN 2206-9658

2020 | Vol. 5 n. I

https://www.journalpublicspace.org

\title{
VIEWPOINT
}

\section{Double P! \\ Public Spaces in Dubai: a Paranoiac Panopticon}

\section{Therese Chidiac}

Politecnico di Milano, Italy

therese.chidiac@polimi.it

\begin{abstract}
Despite the crisis of the metaphoric growth of its superficiality to its deadening sterility, Dubai stands as an attractive destination in the desert simulating a collage of cultural images from around the world with a centrally-planned free market capitalism attracting investors and developers. This paper is part of my master in architecture thesis at Politecnico di Milano titled: $5 \mathrm{~km} / \mathrm{hr}$ Manifesto and it outlines the problematical aspect of Dubai DNA: Dubai public spaces. The city is metaphorically analysed, as a collage city of exogenous fragments and a system city resembling a biological cell with defects in it's the so-called public spaces that are designed as a model of a virtual panopticon of social surveillance forged by a set of do's and don'ts. Built up rapidly over the past few years on the wealth gotten from oil, public spaces in Dubai have no depth of history or indigenous culture, no complexity, no conflicts, no doubts, nothing to stand in the way of its being shaped into the ultimate wonderland. The Arab notion of public has been dramatically ignored in the planning of the city and has been replaced with a collage of regulated western modernist spaces that have failed to create pockets of interaction and communication bringing in mind a problematical situation and an utopic question: How to demystify the panopticon effect and make Dubai more liveable? This leads to the recall of the qualities of the endogenous Arabic Public Space: The Souk. A set of characteristics has been concluded and if integrated, might really change Dubai public spaces from a paranoic panopticon to a more liveable space. Enclosure and privacy, human scale and density, the stage and back stage effect were essential conditions in the souk and are elaborated in this paper presenting a set of new design guidelines for claiming back what is supposed to be public and might develop into further future research.
\end{abstract}

Keywords: public spaces, Dubai, panopticon, surveillance, souk, design guidelines

To cite this article:

Chidiac, T. (2020). Double P! Public Spaces in Dubai: a Paranoiac Panopticon, The Journal of Public Space, 5(I), 247-262, DOI OI I0.3289I/jps.v5il.II4I

This article has been double blind peer reviewed and accepted for publication in The Journal of Public Space.

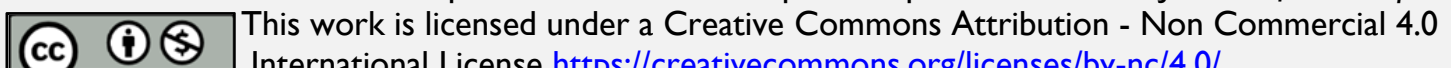
International License https://creativecommons.org/licenses/by-nc/4.0/ 


\section{Introduction}

Only a few years ago, the world became familiar with Dubai. The instant global metropolis with a continuously changing skyline enchanted the world with recordsetting skyscrapers, fake lakes, indoor ski slopes and an impressively multi-cultural population. Through its patchwork of free zones, Dubai had integrated the extraterritoriality concept where the same people would be governed by different legal codes depending on where they were within the city. The free zones made traveling from neighbourhood to neighbourhood, in a legal sense, like moving from country to country. (Brook, 2019) This was at the essence of its free market capitalism economic boom and one can understand somehow how this influenced its urban design of patches and gated cities in one whole master plan with open possibilities. These fragments of investments can be metaphorically compared to a Lego set where there is never ever "nothin' to do". In addition to that, Dubai is a city where everyone and everything in it its luxuries, workers, aesthetics, accents, even its aspirations - were flown in from someplace else. As the locomotive built Daniel Burnham's Chicago, the jetliner built United Arab Emirates Prime Minister Sheikh Mohammed's Dubai. (Brook, 2019) And, despite the crisis of the chaotic and metaphoric growth of its superficiality to its deadening sterility, Dubai stands as a an attractive destination in the desert simulating a collage of cultural images from around the world striving to become a global business hub and attraction centre in the middle east and gulf region.

Many high profile and iconic projects were developed in Dubai, designed to achieve a global city status and image. Burj Khalifa for example in Downtown Dubai has become the signature icon of Emaar Properties. The Dubai fountain and its artificial lake, is another landmark attraction that offers a spectacular waterfront to the tallest tower in the world with 828 meters in height, surrounded by pseudo-Arabian architecture adjacent to the world largest mall. Artificial islands and a myriad of international monuments replicas shaped the rapid growth of the city. One could argue that this is a perfect example of a "Debordian" spectacle in a desert context remote from any contextual relevance (Elsheshtawy, 20I0).

Dubai is using "the spectacle" as a way of impressing the world and placing itself on the map of globally significant cities. It all started with Burj Al Arab that was the first iconic building in the city, the second series of projects were the islands, the fake archipelago, especially Palm island, the third is the ultimate icon, the world tallest building, Burj Khalifa. Here the notion "hegemonic Dubai", a city that declares itself both regionally and globally, is evident. A city-state without income taxes, labour laws, or elections, it is ruled by a corporate oligarchy of hereditary rulers, accountable only to themselves and their investors. A city designed to be a landmark as a whole and in its parts attempting to draw the attention of the world. The French Philosopher pointed out in one of his essay that The society of the Spectacle that the spectacle externality with respect to the acting subject is demonstrated by the fact that the individual's own gestures are no longer his own, but rather those of someone else who represents them to him. The spectator feels at home nowhere, for the spectacle is everywhere. (Debord, 2019) Quite a model for the global future! 
Therese Chidiac

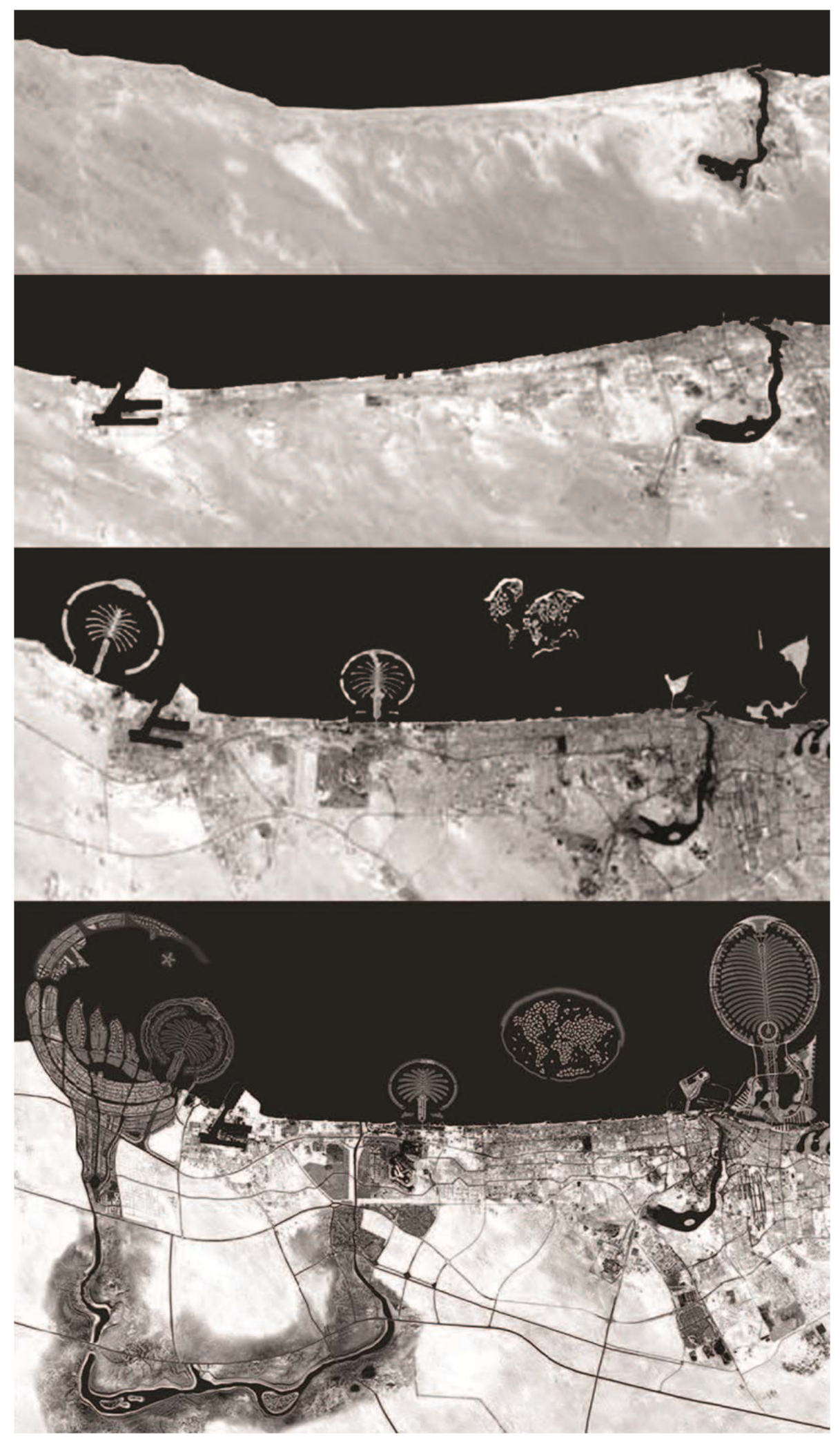

Figure I: Dubai Areial view evolution year 1950, 1975, 2007, 2025 - photos retrieved from Google Earth. 


\section{Dubai Metaphor}

\section{I Collage city}

Postmodernists Guy Debord and Jean Baudrillard have declared that the genuine experience of life has been replaced: "In societies dominated by modern conditions of production, life is presented as an immense accumulation of spectacles." Baudrillard comments on the implications of such simulation: "It is no longer a question of imitation. It is a question of substituting the signs of the real for the real, that is to say of an operation of deterring every real process via its operational double". (Baudrillard and Turner, 1989) Reflecting this on Dubai context, all one can encounter is an accumulation of artificial representations.

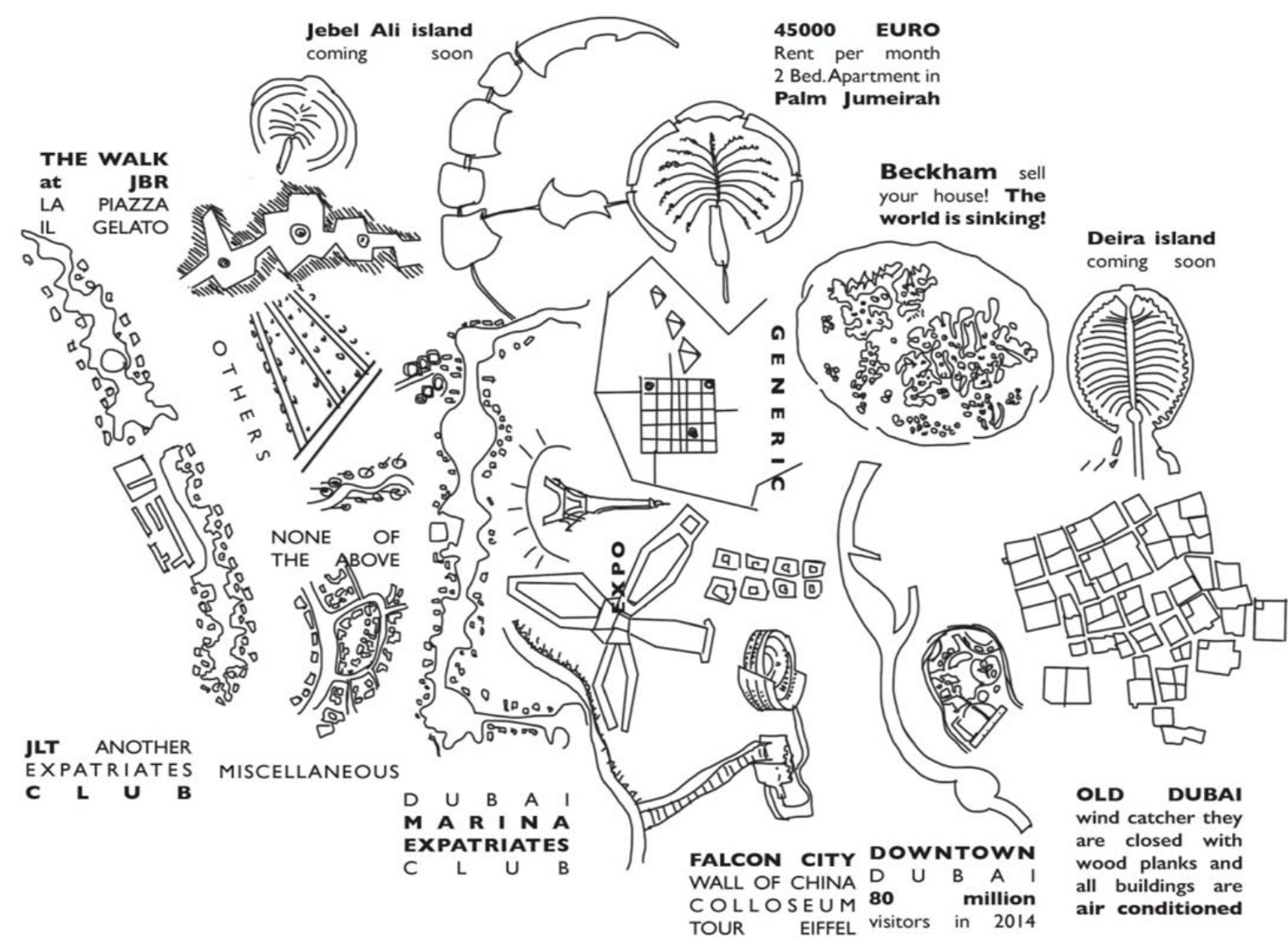

Figure 2: Dubai as collage of fragments - work by author (2015)

The copy has replaced the original. And this is the case that might be distorting realities of things and presenting a delirious urban status that one might get used to at the end and starts to believe in it as the natural model of a city. Historically, a Collage city would offer the poetics of Utopia to the city, virtues and spatial qualities by the juxtaposition and layering of smaller designs into a whole with a chronological and historical order, rather than a totalitarian, fresh slate approach, bringing in all the spectacles at once, that wouldn't allow the city to evolve through the politics of utopia and time. (Elsheshtawy, 2010) Dubai, in its accumulation of artificial representations and fragmentations has lost 
the value of time, of memories and history that usually characterizes resilient cities. The copies have substituted the original without accidently creating any poetic urban pockets. Everything is planned from the top down and critically presenting a "bricolage" of exclusive and gated cities and clubs, a continuous attempt to draw the attention of the world without accounting for its urban life.

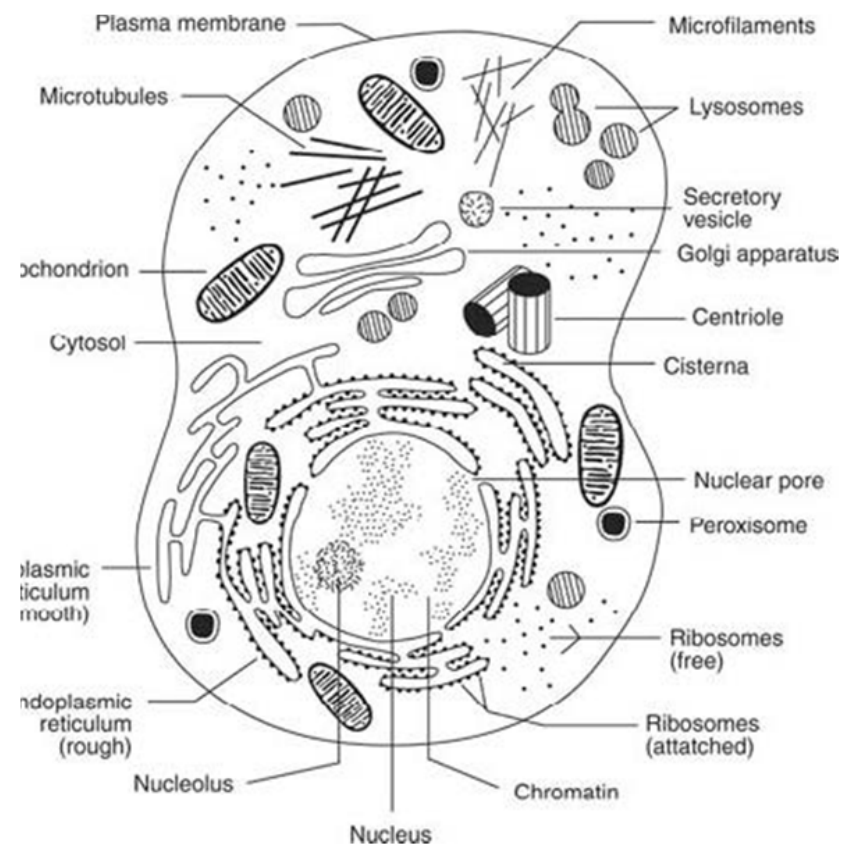

Figure 3: Cell elements (google.com)

\subsection{System city}

From an urban perspective, and due to its highly organized planning and zoning approach, Dubai can be compared in its elements to a biological cell elements as follow (Google.com, 20I5):

The cell membrane: the ring road,

The cytoskeleton: the transportation system

The Cytosol: the Streets

The Cytoplasm: the People flow

The Lysosomes: the Recycling plants

The Mitochondria: the Power station

The Nucleus: The cell city's metropolitan center and public spaces.

The Endoplasmic reticulum: The Industries.

This is a personal metaphor of Dubai to be able to identify its morphology and functionality as a whole organism and in order to spot where Dubai has some nucleus, some public spaces. It can be clearly seen that it is a linear city, decentralized and out of human scale with a network growth all along its transportation system. Like a series of spectacles spread all along the coastal city highway creating an impressive skyline to be captured in a tourist photo! 


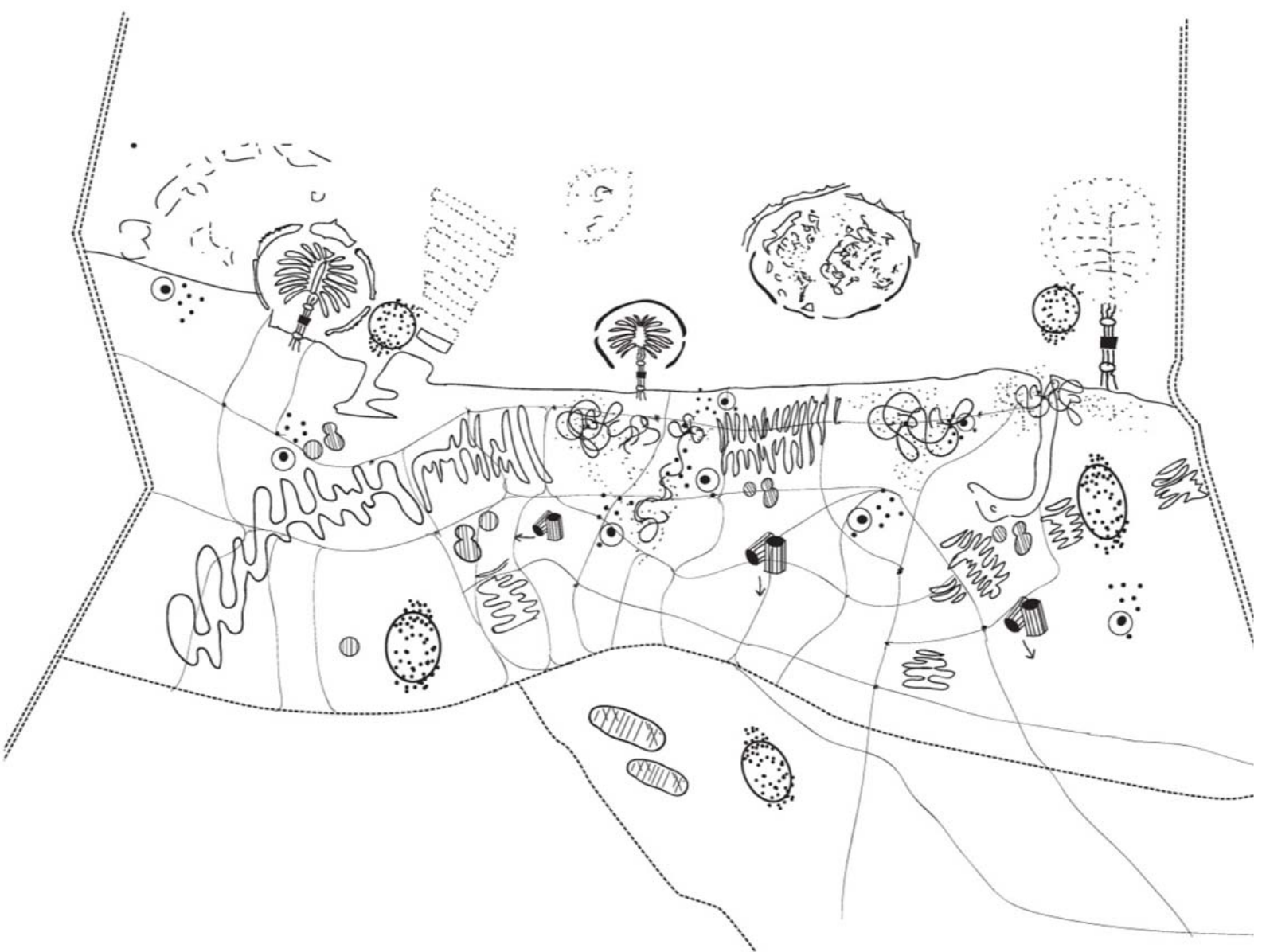

Figure 4: Dubai metaphor as a system city - work by author (2015)

\section{Defects in the urban DNA of Dubai}

Public spaces are crucial to the sustainability of cities for political, social, economic, public health and biodiversity reasons (Banerjee, 200I). However, Dubai public spaces weren't given that importance due to the processes of privatization taking place that has given rise to a city form less and less docile to the daily co-presence of a diversity of urbanites. And the existing public spaces in the privatized patches of Dubai are a collage of spaces and fragmented presenting many defects that are controversial with the functionality of a public space.

As globalization neuters local cultural differences and identities, the traditional Arab notions and configurations of the public realm and the urban circulation network have dramatically given way to Western modernist models in Dubai. The American superhighway and the Le Corbusian superblock have joined with the European roundabout to make for both difficult vehicular and pedestrian circulation, with a dearth of popular, pedestrian-scaled outdoor public spaces and with a "shadow" private transit system for its large foreign labor force, as well as continuing tribal hierarchies and a pervasive mobile phone and email culture. (Elsheshtawy, 2010) The defects in these main public spaces present a set of problematical aspects that might go unnoticed by 
citizens or tourists. Dubai vibrant public spaces are in the Downtown, the Marina Walk, in Jumeirah Beach Resort, in the Mall and many other places that are very significant for the city as they are "heaven for the city multi-ethnic community".

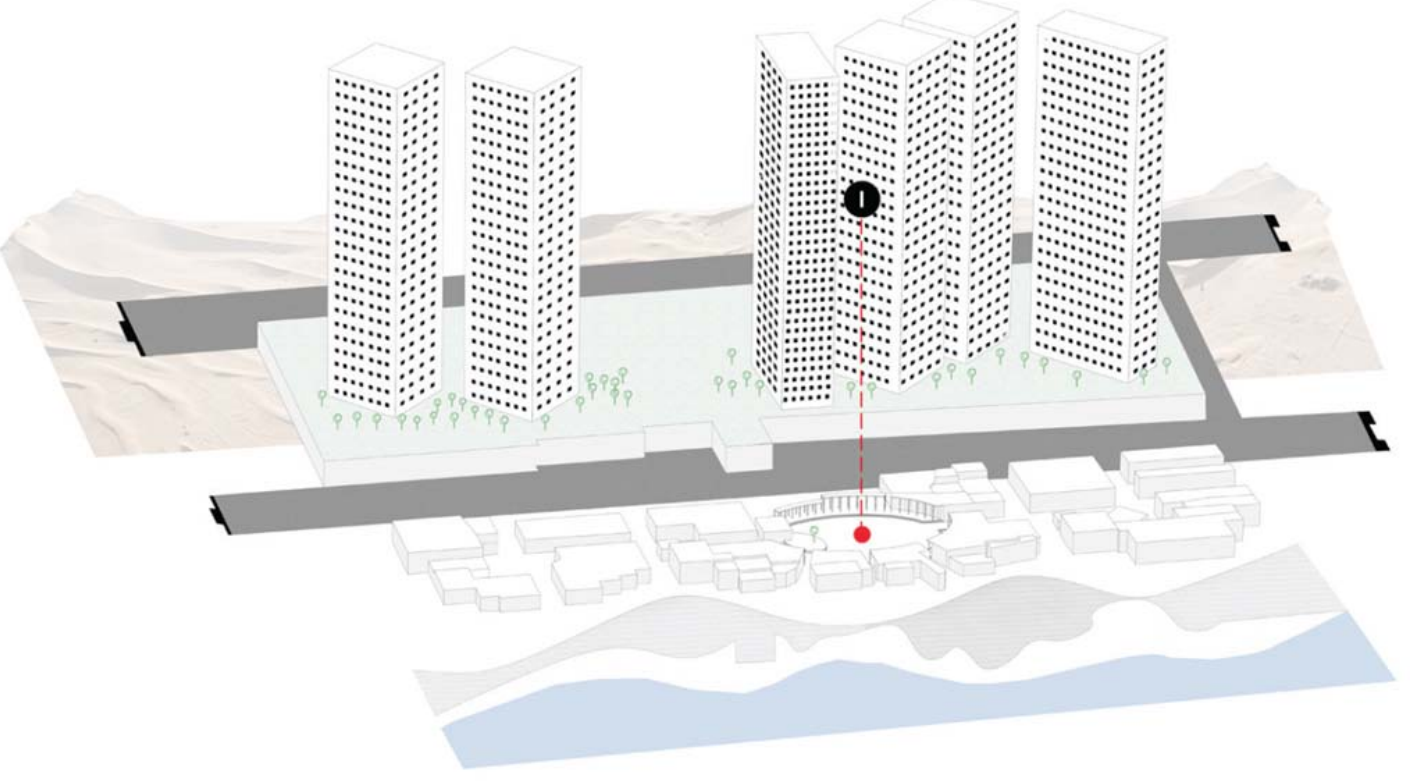

Figure 5: I: Jumeirah Beach Resort JBR "PIAZZA" diagram - Fake Emulation of Piazza del Popolo of Roma work by author (2015)

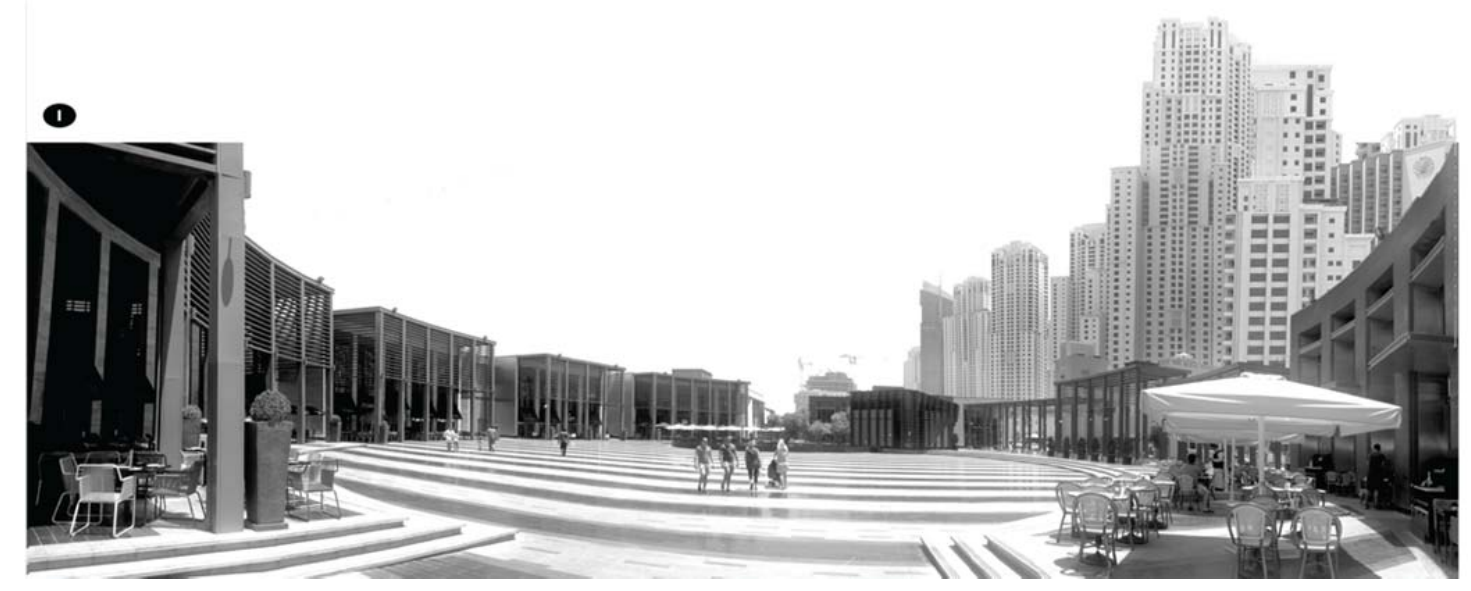

Figure 6: Jumeirah Beach Resort JBR "PIAZZA" - photo by author (2015) 
Double P!

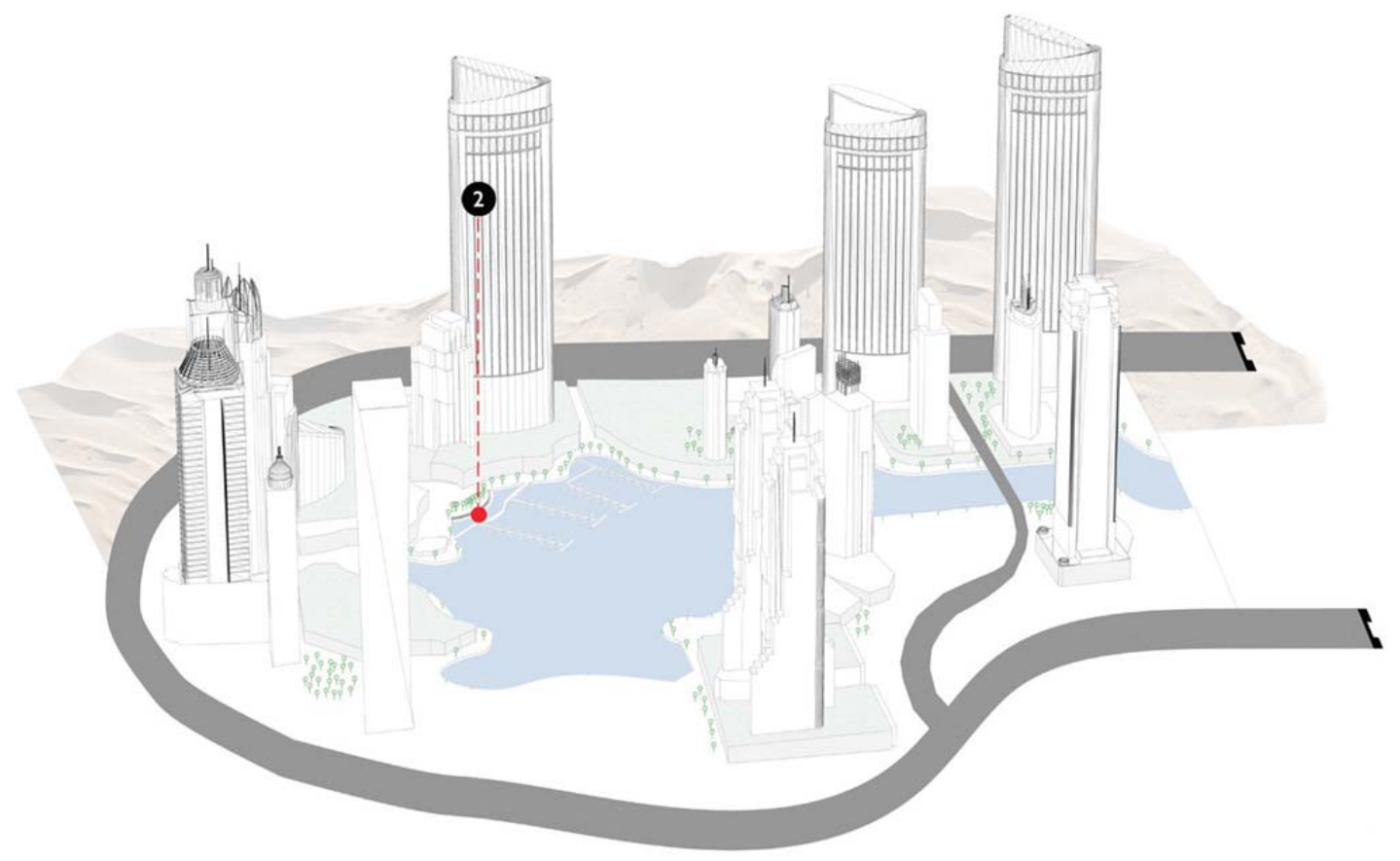

Figure 7: Dubai Marina Walk - Emulation of canal city concept - work by author (2015)

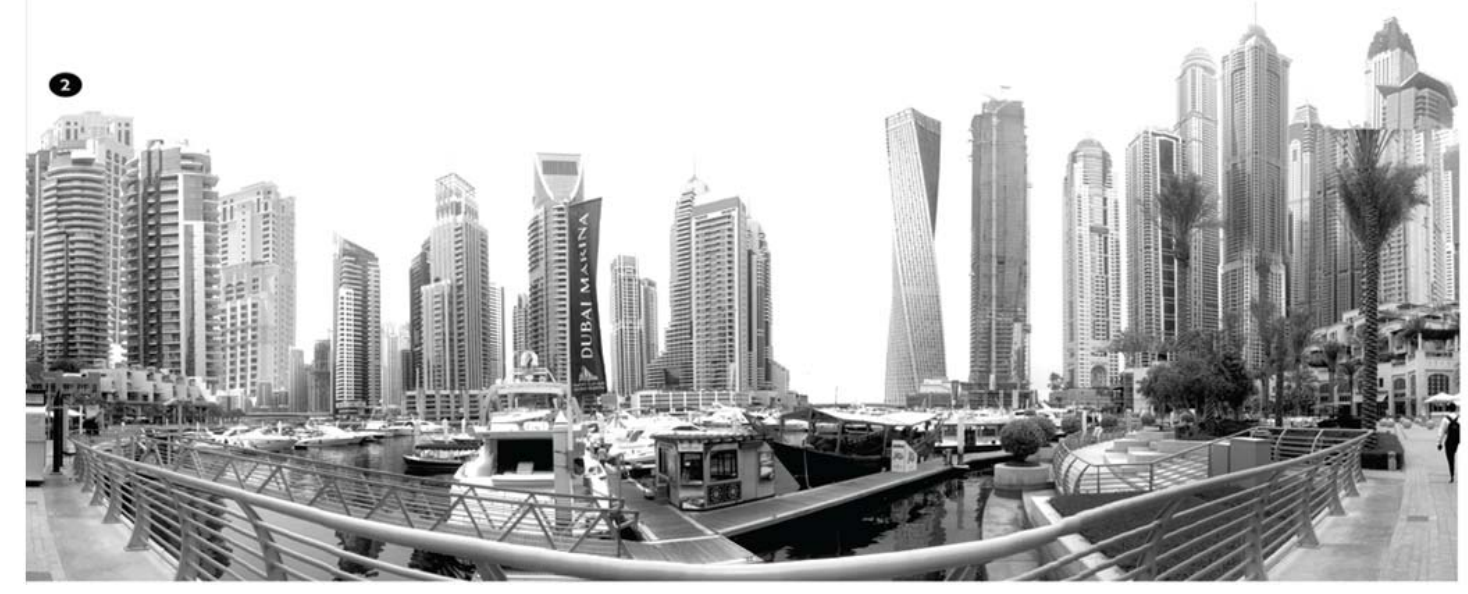

Figure 8: Dubai Marina Walk - Emulation of canal city concept - photo by author (2015) 
Therese Chidiac

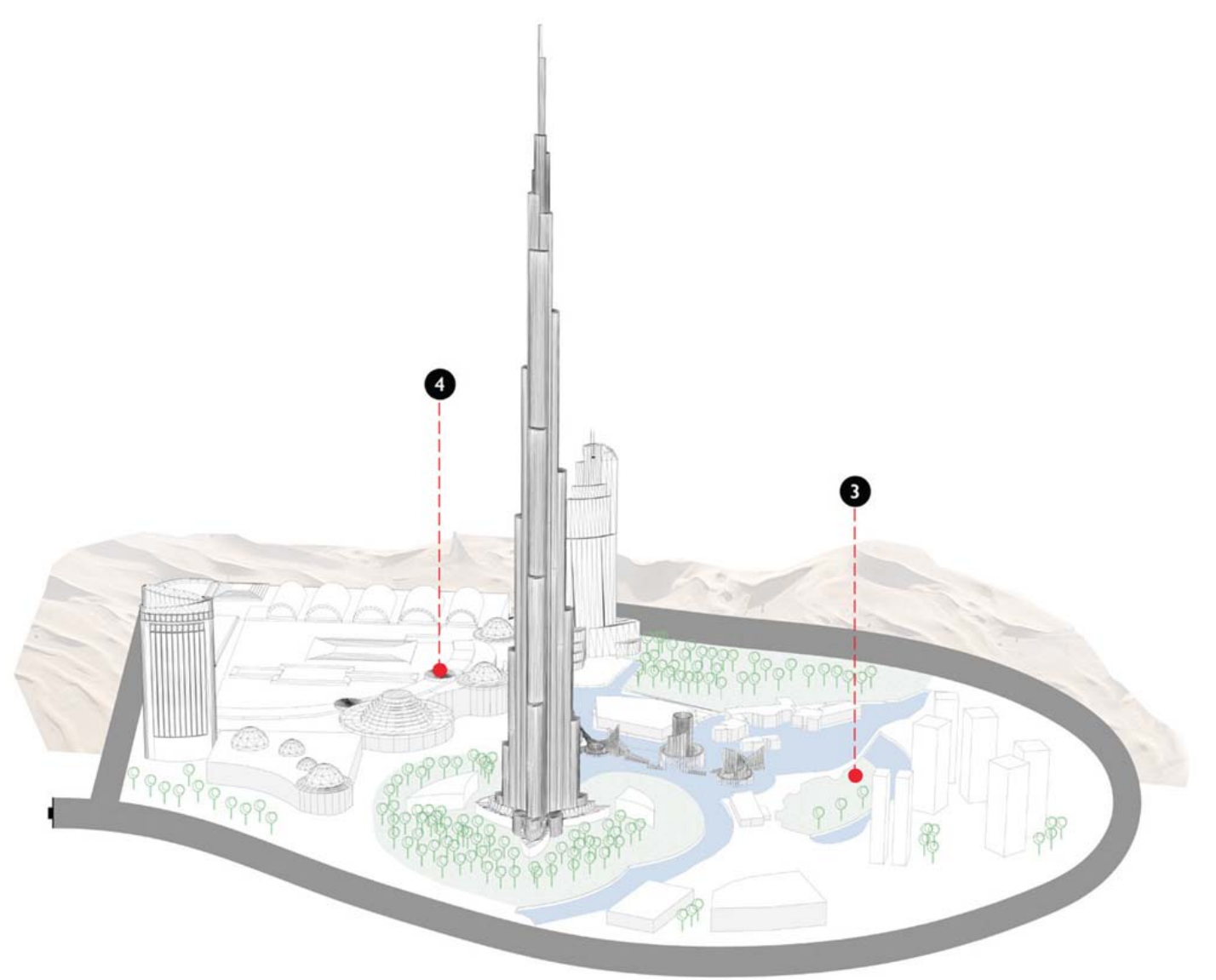

Figure 9: Downtown Dubai - Emulation of Las Vegas dancing fountain - work by author (2015)

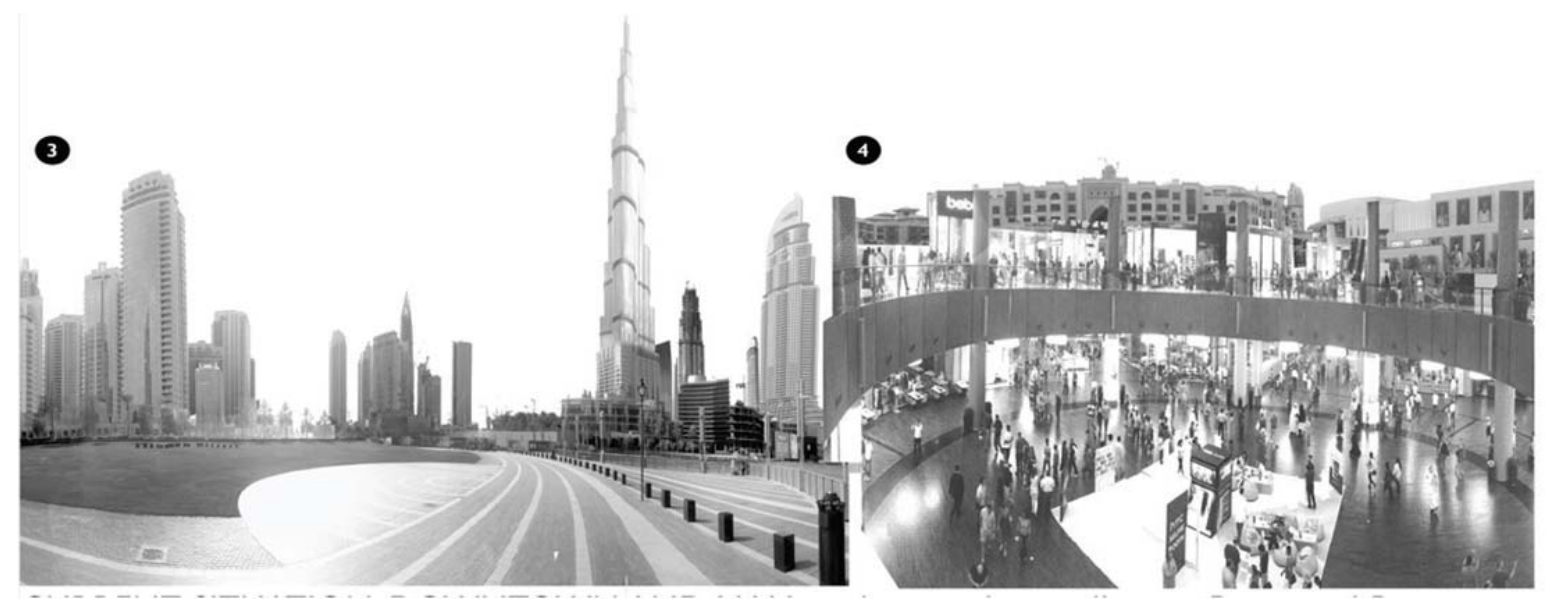

Figure 10: Downtown Dubai green space and Dubai Mall - photo by author (2015)

\section{3.a Panopticon effect}

Dubai is a city with very few public spaces, which means that with this scarcity concept, public spaces have monetary value and are unavailable to the masses anytime. Having money becomes essential to be part of the city and to belong to it. 
Dubai is usually referred to as "a global city", "a city-corporation", or "Brand Dubai". Large corporations such as the construction company Emaar, Dubai Holdings, Nakheel, Emirates Airlines, the Investment Corporation of Dubai or the retail development company, Dubai World, were funded with the goal of employing a strong influence on not only the economic, but also the public and social spheres of the city. (Rodriguez Roldan, 2013)

Thus, public spaces has become part of the luxury and showcased by the developers, a gated space, where you stand behind its vitrine to contemplate it while being under surveillance, very similar to a model of a virtual panopticon of social surveillance forged by a set of do's and don'ts. A paranoic panopticon defying the notion of public! As Michel Foucault ( 1984) states: "Power is everywhere; not because it embraces everything, but because it comes from everywhere"

Since large corporations and real estate development companies operate in Dubai providing property development and management services, they set of restrictions and Do's and Don'ts or what is formally called Master Community Rules. For example in Emaar Rules report for the Marina and Downtown, it is clearly mentioned that "Community rules are for the benefit of owners and residents and are designed to create an environment in which all owners and residents can maximize enjoyment of their homes and the various common areas and facilities. It is also the intent of these Rules to create a serene, attractive and safe environment for the residents, and guests of the Community and Master Community. Adherence to these rules will maintain, preserve, enhance, and protect the property values and assets of the Community. Violation of any of the Community Rules will be uniformly enforced, with a Notice of Violation and applicable Violation Penalty." (Ecm.ae, n.d.)

In addition to that, the variety of semi-public spaces in Dubai are also managed by private-public or entirely private partnerships and thus, questions the notion of public space inherited from a legal perspective.

Every bit of land in Dubai is regulated by the laws of property and by the harsh weather conditions making it difficult to consider anything as common without encountering an entitled owner and manager.

"He who is subjected to a field of visibility, and who knows it, assumes responsibility for the constraints of power; he makes them play spontaneously upon himself; he inscribes in himself the power relation in which he simultaneously plays both roles; he becomes the principle of his own subjection" (Foucault, 1995)

\section{3.b The exogenous spaces}

The European notion of public space as the Greek agora and the Roman forum to the Renaissance square, until the nineteenth century railway station, taken as ideal models of public arenas where the public affairs of the city are discussed among an assembly of equal citizens is totally different from the Arab notion of public space where the street, the souk and the market have gathered the daily interactions of the citizenry. 


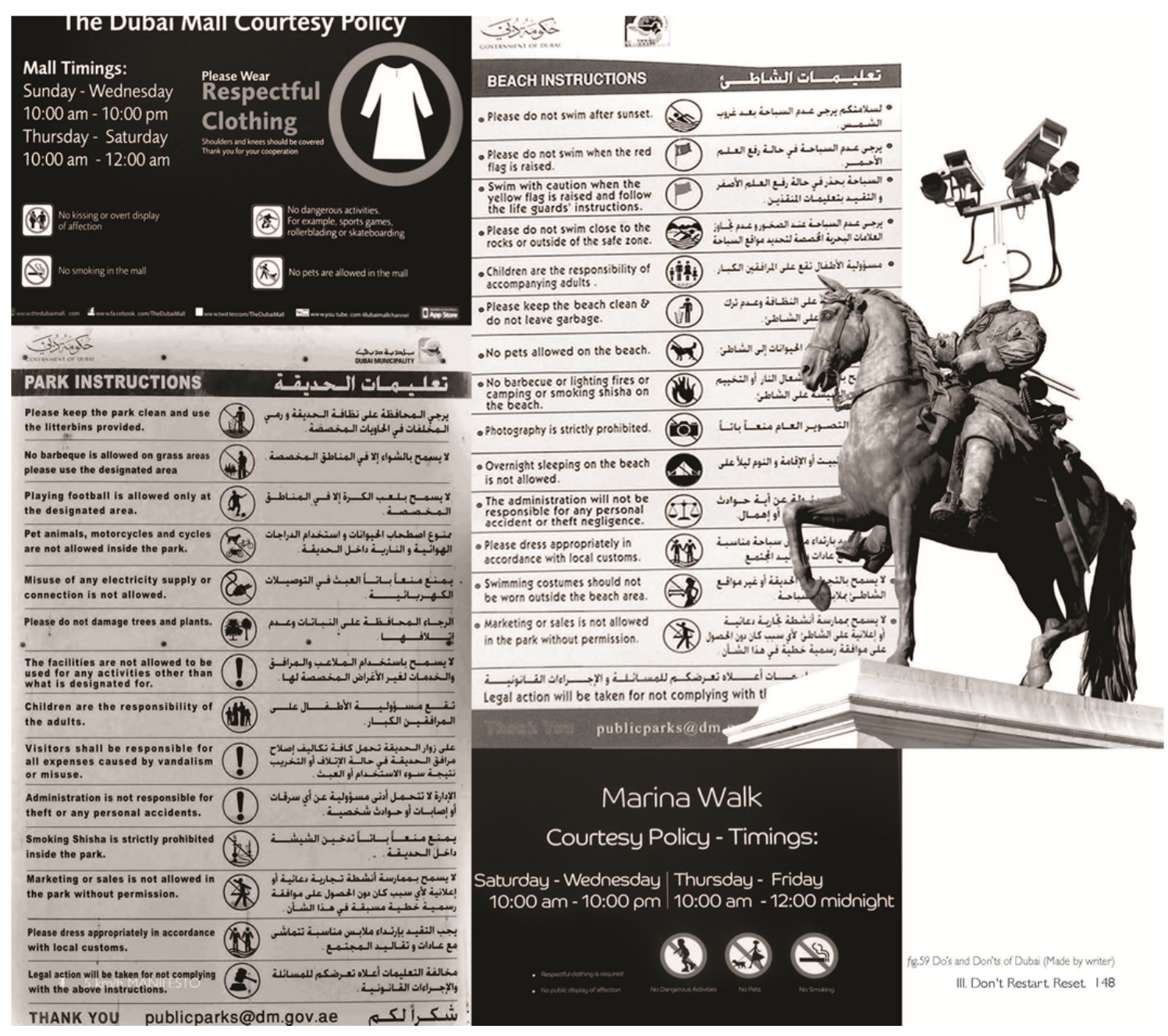

Figure II: do's and don'ts - work of author (20I5)

Besides the surveillance issue, the debatable act is the one of injecting exogenous spaces such as the piazza del Popolo or a canal city or Vegas fountain in a cultural context historically developing a democratic anarchical system based on the souk concept. Facing the present situation that cannot be undone, maybe for political and power statement reasons, standing from an utopic perspective, one can question how to break down the fixed and known into particles of the unknown from which a new "public" quality may emerge. And, how to detach the "public" space from the rules of control without breaking any single rule, how to create pockets for social interaction claiming the right to the city respecting the developers' regulations in the public space in order to make Dubai more livable?

\section{The endogenous qualities of Dubai}

Old Dubai developed with a very effective and sustainable design of the houses to deal with extreme temperatures. Density and proximity were a way to reduce the effect of 
the heat, the houses were built very close together forming narrow passages shaded as much as possible during the day. The narrow passages are opened to small squares with a panoramic view the surrounding. This arrangement increased airflow in the street, a technique used by Arabs for centuries. (Zeballos, 2010)
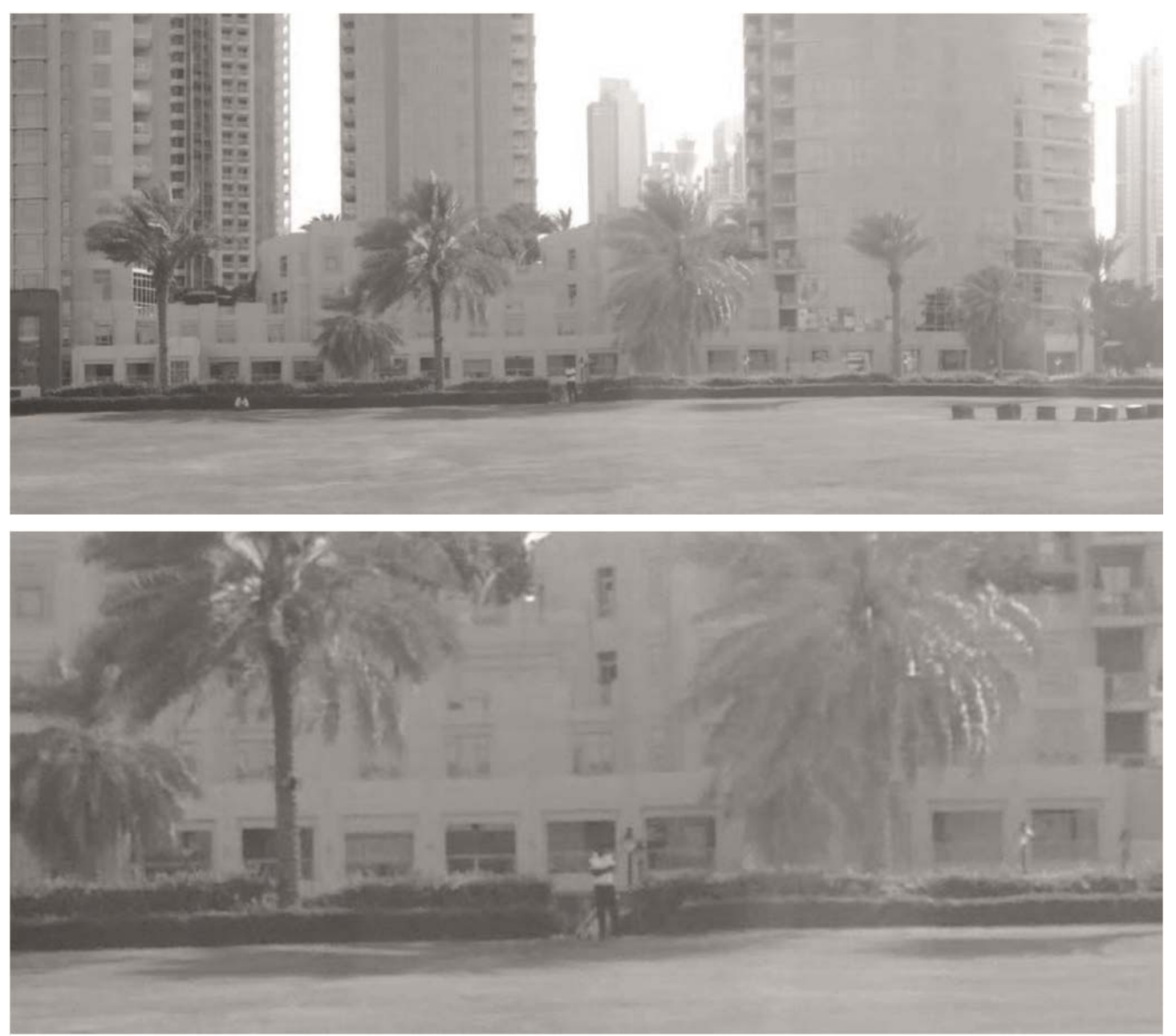

Figure 12: Security guy in the green "public" space of Downtown Dubai - Photo by author (2015)

4.I The Souk: the public space

While historic Arab cities show a variety of origins and growth patterns, they were nonetheless established by a common set of social, geographic, and religious factors leading to similar morphological principles developing the urban fabric. The traditional Arab city was built at a pedestrian scale and was based on the pedestrian movement, as such, was an extremely dense cityscape with a very high degree of complexity. The public space was the street or the souk, the main exchange linear market place or the corridors between residential buildings. The sequence established a clear hierarchy and punctuated changes through transition, and with it, changes in social behavior and norms. 


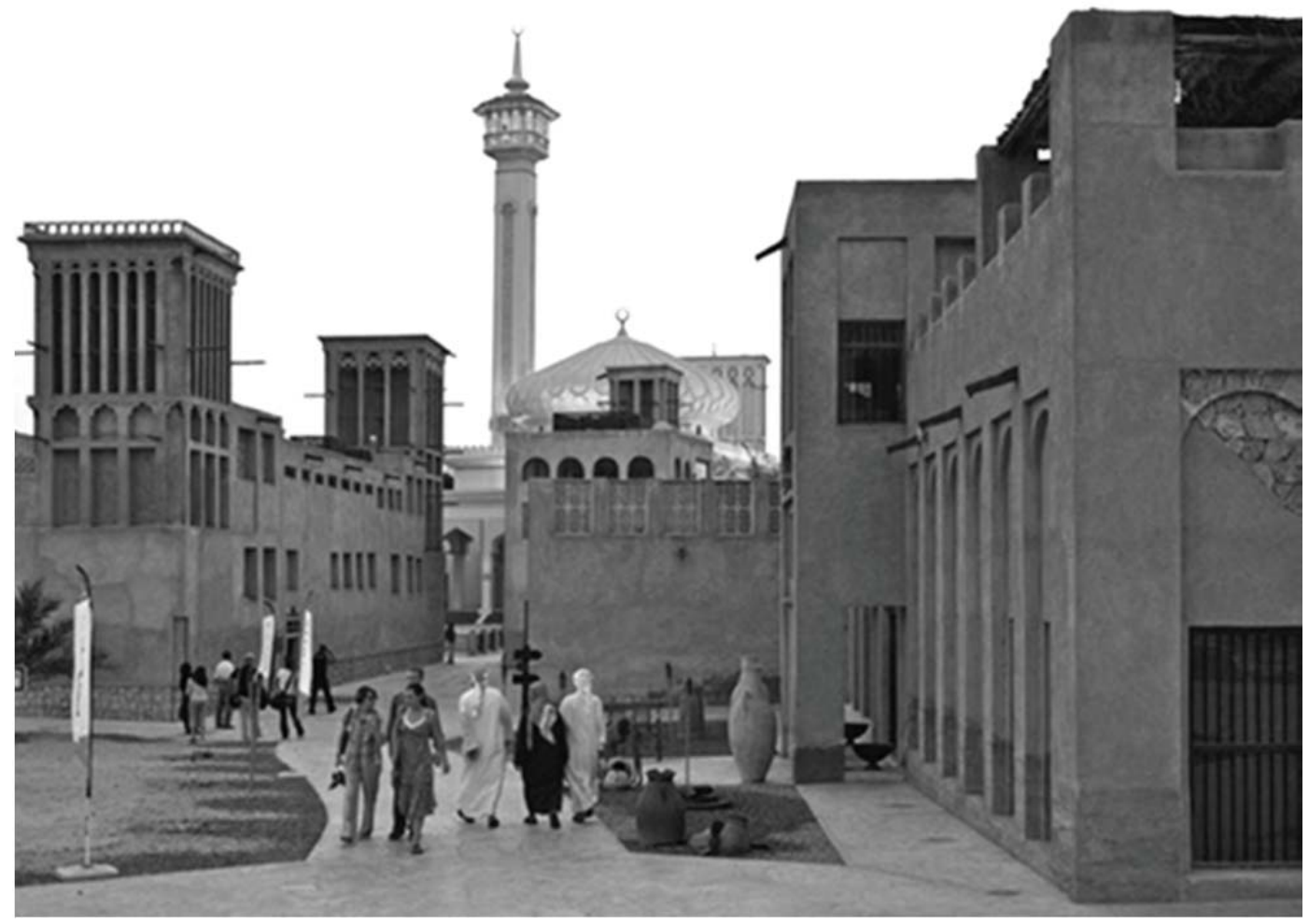

Figure 13: Old Dubai, Al Bastakiyya restored district - photo by author (20I5)

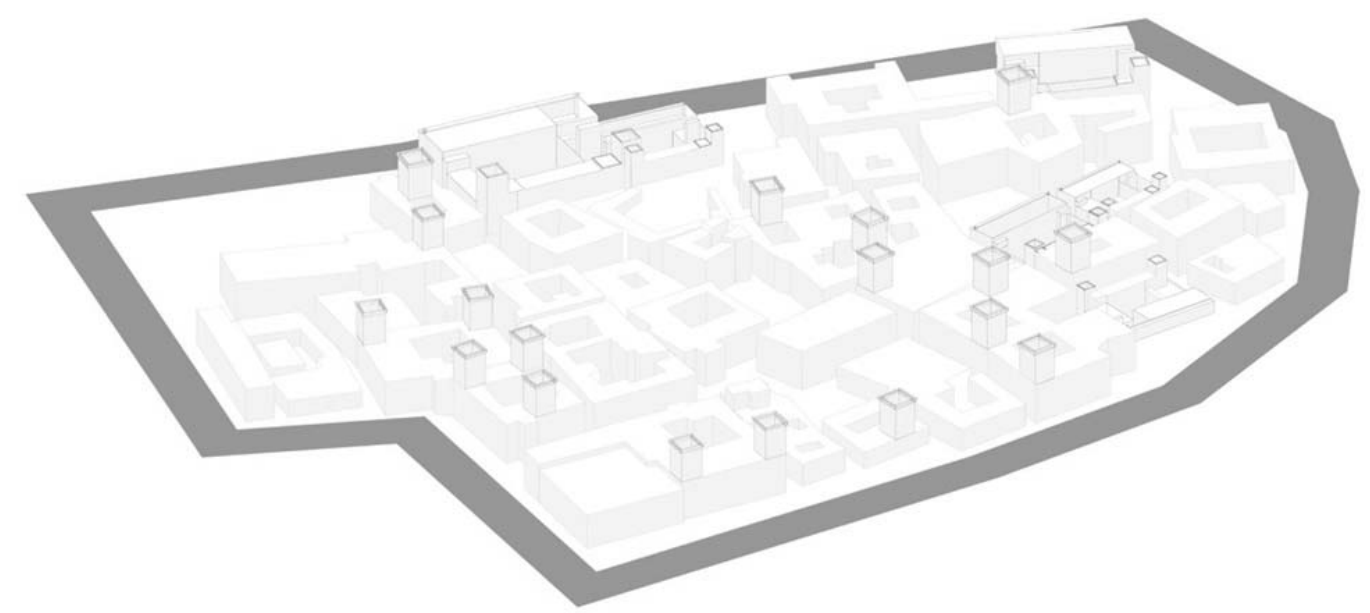

Figure 14 Old Dubai, Al Bastakiyya restored district - work by author (20I5) 


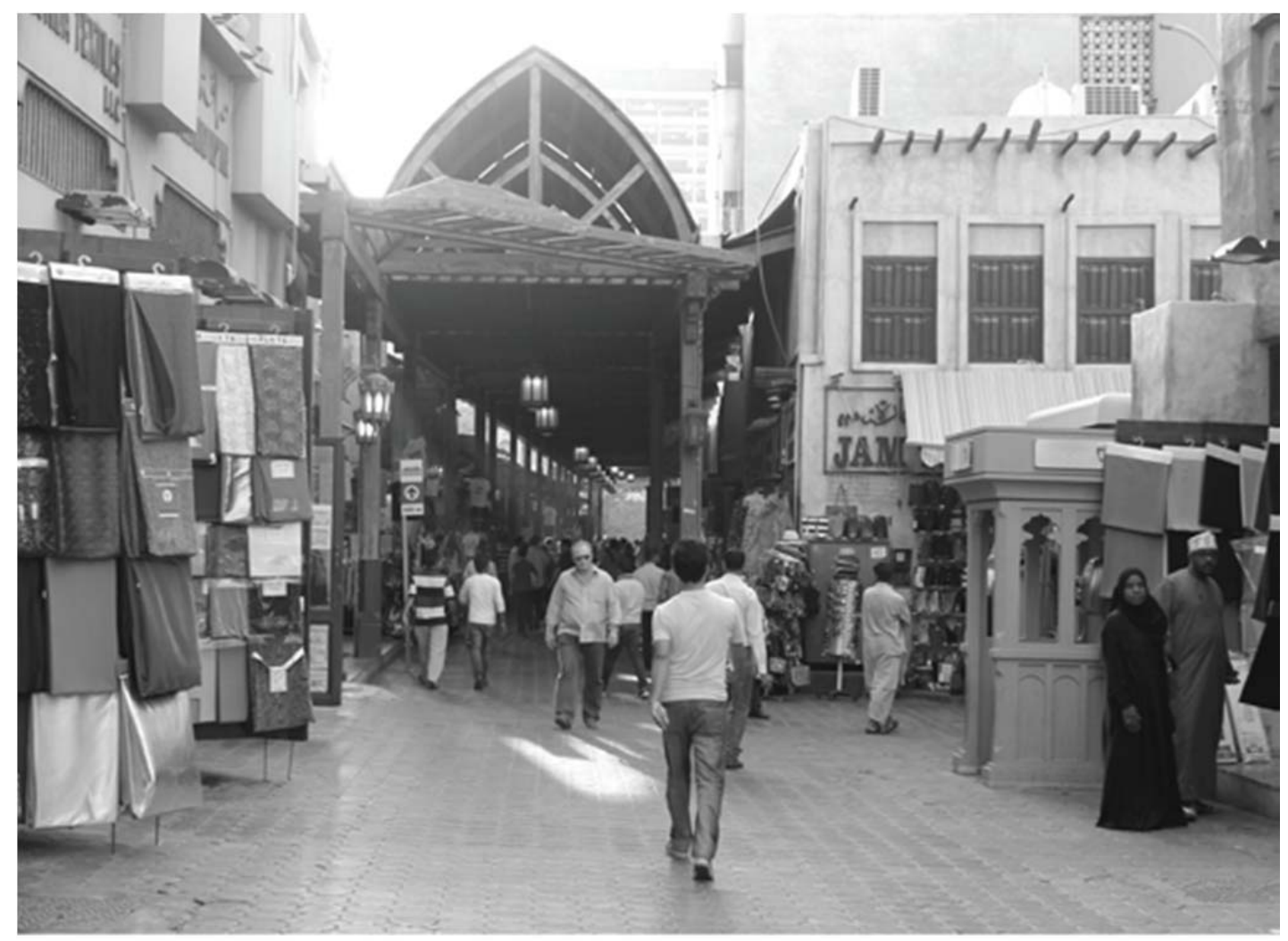

Figure 15: Old Dubai, Gold Souk covered with Persian influence - photo by author (2015)

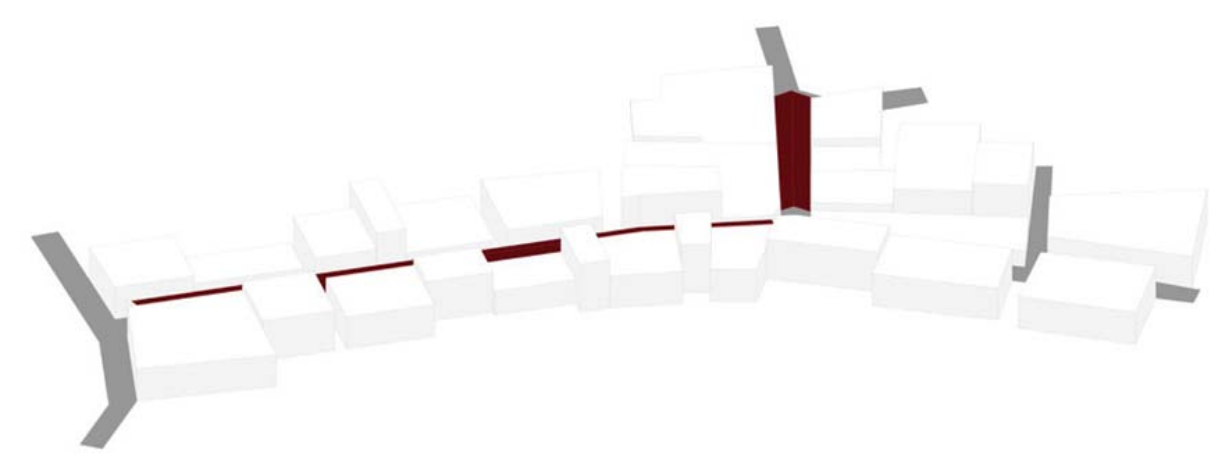

Figure 16: Old Dubai, Gold Souk covered with Persian influence - work by author

\subsection{Design guideline I: HIDE for Enclosure}

The Souk's enclosure and privacy are an essential condition for its existence at first place. A design language implementing these notions will aim to break down previously known thresholds in the city of Dubai and create change in the way people perceive, 
use, and experience an open and meaningless space. It would create pockets of uncertain and unpredictable interaction and uses. It would seek to answer not only to blur the boundaries that create separations between public and private spaces, but also how to bring the rich civic and communal lifestyle to exist on the ground.

\subsection{Design guideline 2: DIFFUSE for Human Scale}

Density is a way to create pockets of "private" activities, escaping psychologically the Panopticon effect. Power and social surveillance will exist, however when the collective flow is brought into a dense space, the civil inattention will increase and thus the probability of interaction will increase as well. Imagine one person walking alone in an open piazza knowing that he is being watched continuously, and imagine twenty people in the same scenario. Density is a way to provide a comfortable psychological attitude to the public space of Dubai.

Density must be to human scale, anarchical and modular; and should allow people to have control of the space especially in out of scale context such as the Marina Walk or Dubai Downtown.

\subsection{Design guideline 3: BUFFER for Open Possibilities} Introducing the Spectacle and Stage Backstage effect with a buffering approach stimulates the creation of different level of public and semi-public interactions. Buffering a public space from another public space by adding an in between public space! This will create pockets, hidden from the surveillance, and will increase psychological comfort in the space. Creating gaps in between spaces for open possibilities and future space of exchange that keep changing on daily basis is just like the Souk effect.

\subsection{Design guideline 4: CONTINUE to Change Real Time}

In Dubai, the spatial experience in a public space is limited by the Panopticon effect. Testing the change on one public space should continue to another, testing again and again. Ephemeral installations and experiments can help to complete the feedback loop and insure the continuity of interventions encouraging a continuous flow of people, of atmosphere and of events.

\section{Conclusion}

After showcasing the delirious spectacles of Dubai urban mesh and its metaphorical representations and after highlighting the problematical issue in the conception of its exogenous public spaces that represent a Double $\mathrm{P}$ scenario of a paranoiac panopticon, we can conclude that the presented design qualities in the guidelines are worth to be put into action. Since it is a city of experimentations, of trial and errors with the objective to be the best, it can bear a series of interventions that might make it more livable. And here comes the social responsibility of the architects in charge, they have the tools to integrate smooth design guidelines for public spaces and negotiate the regulations of the developers to end up with a win-win situation. 


\section{References}

Baudrillard, J. and Turner, C. (1989). America. London: Verso.

Banerjee, T. (200I). The Future of Public Space:Beyond Invented Streets and Reinvented Places. lournal of the American Planning Association, 67(I), Pp.9-24.

Brook, D. (2019). A History of Future Cities I W. W. Norton \& Company. [online] Books.wwnorton.com. Available at: http://books.wwnorton.com/books/A-History-ofFuture-Cities/ [Accessed 12 Apr. 2019].

Debord, G. (20/9). [online] Theanarchistlibrary.org. Available at: https://theanarchistlibrary.org/library/guy-debord-the-society-of-the-spectacle.pdf [Accessed 12 Apr. 2019].

Ecm.ae. (n.d.). Emirates living master community rules. [online] Available at: http://www.ecm.ae//media/projects/ecm/pdfs/documents-andpdfs/emirates_living_master_community_rules.pdf?la=en\&hash=F6E22D89DEBF96043 I8I3 F0707FDDBBD95D60726 [Accessed I 2 Apr. 2019].

Elsheshtawy, Y. (20I0). Dubai. London: Routledge, pp I72-173

Foucault, M. (1995). Discipline and punish. New York: Vintage Books, pp.202-203. Google.com. (20I5).

Rodriguez Roldan, M. (20I3). Morous Globalizing City vs. A Content. [online]

Commons.trincoll.edu. Available at: https://commons.trincoll.edu/cugs/files/20 I4/I I/RoldanMonica-I3-Thesis-final.pdf [Accessed I2 Apr. 2019].

Zeballos, C. (2010). The other side of Dubai: Wind Towers. [online] Architecturalmoleskine.blogspot.com. Available at: http://architecturalmoleskine.blogspot.com/20l0/0l/other-side-of-dubai-wind-towers.html [Accessed I2 Apr. 2019]. 